\title{
Analysis of the Current Clinical Research Management System of Investigator Initiated Trials in China
}

\begin{abstract}
Objective: With the rapid increasing clinical trials in China in recent years, there has been rising concern on the management of investigator initiated trials. Compared with the trials sponsored by pharmaceutical companies, IIT is facing practical challenges in China due to the lack of experience by investigator and immature regulatory circumstances. We conducted an internet-based survey to understand the overall picture of IITs management in China.
\end{abstract}

Methods: An internet-based questionnaire was developed and the staff of clinical trial offices from different types of hospitals was invited to provide response via mobile based App or online website in 2 weeks. We have collected the responses from the following aspects: administrative and governance infrastructure, ethical review, project management, funding resources and research staff management.

Results: From December 8 to 20, 2016, a total of 259 responses were collected from the staffs that are mainly responsible for the clinical trial management and scientific research based in the different clinical facilities.

Conclusion: In China, three key factors are important to improve the management on IITs: funding support, staffing resourcing and regulatory guidance.

Keywords: Investigator initiated trials $\mathbf{\text { S Survey }}$ - Management $\mathbf{- ~ C h i n a ~}$

Submitted Date: 21 November 2017; Accepted Date: 06 December 2017; Published Date: 12 December 2017

\section{Introduction}

The number of clinical trials in China has increased rapidly in recent years. According to the data available on the two clinical trial registries in the U.S. (www.clinicaltrials. gov) and China (www.chictr.org.cn), not only the number of clinical trials for new drugs, new medical devices and in vitro diagnostic assays has increased, but also a considerable amount of non-profit, postmarketing research are conducted by nonpharmaceutical organizations, including academic and government institutions. These trials, known as Investigator Initiated Trials (IITs), are usually sponsored by investigators or academic groups in China, similar to the rest of world.

Unlike IITs in USA or EU, where investigators are more experienced and compliant with ICH in a well-regulated environment, IITs were not well regulated by the agency in China previously. Dr. Yang Zhi-Min, the clinical reviewer head of CDE clinical oncology department has published
Ye Cao ${ }^{1,2, \#, ~ X i n ~ W a n g}{ }^{3, \#,}, Y u$ $\mathrm{CaO}^{4}$, Fuyu Song ${ }^{5}$, Silvia Minelli², Jibin $\mathrm{Li}^{1,2}$, Kexin $\mathrm{Li}^{3, *}$, Minghuang Hong ${ }^{1,2, *}$

'Department of Clinical Research/ National Clinical Trials Institute of Cancer Center, Sun Yat-sen University, China ${ }^{2}$ State Key Laboratory (SKL) of Oncology, South China

${ }^{3}$ Clinical Trial Center/National Clinical Trials Institute of Beijing Hospital, National Center of Gerontology, China ${ }^{4}$ National Clinical Trials Institute of the Affiliated Hospital, Qingdao University, China

${ }^{5}$ Center for Food and Drug Inspection, China Food and Drug Administration, Beijing, China

\#Co-first author

*Author for correspondence:

E-mail: zwp2000@suzuka-u.ac.jp 
the standing points of IIT management in China, firstly declaring that the basic principles of IITs regulation in China is similar to United States [1]. On October 16, 2014, the National Health and Family Planning Commission of the People 's Republic of China (NHFPC), China Food, have published Management Practices for Clinical Research Projects Carried Out by Medical and Health Institutions and Drug Administration (CFDA) and the State Administration of Traditional Chinese Medicine as a joined guidance document [2]. This document outlines the management requirement of clinical research at clinical facilities. It is a major progress to the management of IITs in China. Besides that, NHFPC released a guidance named as Regulations for the Ethical Review of Biomedical Research in Human, which was effective on October 12, 2016 [3]. This is also another important milestone to IITs in China, providing a regulatory guideline for the ethical review to all human biomedical research, including IITs.

Unlike the pharmaceutical companies, organizations or clinicians would face more challenges worldwide on IIT planning, conduction, funding resources, project oversight, ethical review and research staff management. Given the rapid development of IITs in China and the growing awareness of the importance of IITs in academic and medical institutions, understanding the overall picture of IITs management in local hospitals becomes urgently required. However, so far there is no published data to illustrate the overall IIT development status, especially the management aspects in China. Here we reported an internet-based survey to understand the overall management situation of IITs in local hospitals.

\section{Methods}

Questionnaire is developed via an online questionnaire tool (www.wenjuan.com). It can be accessed using desktop or mobile devices to answer the questionnaires and then submitted online. This internet based questionnaire was forwarded to 5 online clinical study discussion forums or professional groups on We Chat. Nearly 1500 members have been invited. Because the targeted responders of the survey are full-time staff working in the medical institution, an alert is popped out to request the participation of qualified respondents only.

The questionnaire covered major aspects of IITs management. It includes one cloze question, 21 single choice questions, and one multiple choice. Following sections are available:
Section 1: The hospital characteristics where responders work $(\mathrm{Q} 1$ - Q6). In order to collect the information precisely from clinical institutions only, Question 1 requested the provision of the hospital name where they work and we did not report the hospitals surveyed for privacy reason in this paper. Responders working for the pharmaceutical enterprises or non-clinical institutions will be excluded from the analysis. The type of the hospital (public or private), hospital beds and CFDA certification status (Only CFDA accredited sites are allow to run IND studies) were collected in this part of questions.

Section 2: Active IIT projects and management infrastructure (Q7 - Q9). This part of questions was aimed to learn the number of active IIT projects, the availability of a dedicated IIT project governance body, management process as well as the implementation of standard operating procedure (SOP).

Section 3: The management of IIT projects (Q10 - Q16). This part was aimed to learn the process management in following aspects: IIT registration and technical assessment, ethical review and approval criteria, quality control on IIT project, IIT data collection process and database management, clinical trial insurance coverage status for any interventional IIT project, and registration on public platform for any IIT project.

Section 4: Support for IIT projects (Q17 - Q23). These questions are designed to understand the current funding and resourcing issues in IIT projects, including: whether the fund covers the salary of research staff; whether a dedicated full-time clinical research coordinators (CRC) or nurse is assigned to the project; the relevance of IIT projects and the development of related academic area; expression of interest to clinical staff towards in IITs; and the current limitation of IIT project development in China.

\section{Statistical analysis}

In this survey, the data of each selection under each question is presented in number and percentile. We assessed the relationship in several key indicators. ChiSquare test is employed and $\mathrm{p}<0.05$ is considered as statistically significant difference at a two-sided level.

\section{Results}

Survey was conducted from December 8 to 20 2016. A total qualified 259 respondents from 231 hospitals have provided feedback. Most feedback was management staff of clinical trials in clinical sectors. A 
small number of respondents are clinical investigators. The geographic distribution of respondents is shown in Figure 1. It has shown that our respondents are mainly from eastern China where the most activity has on clinical trial conduction. The completion time of survey was 6 minutes and 22 seconds on average. The survey results were summarized in Table 1.

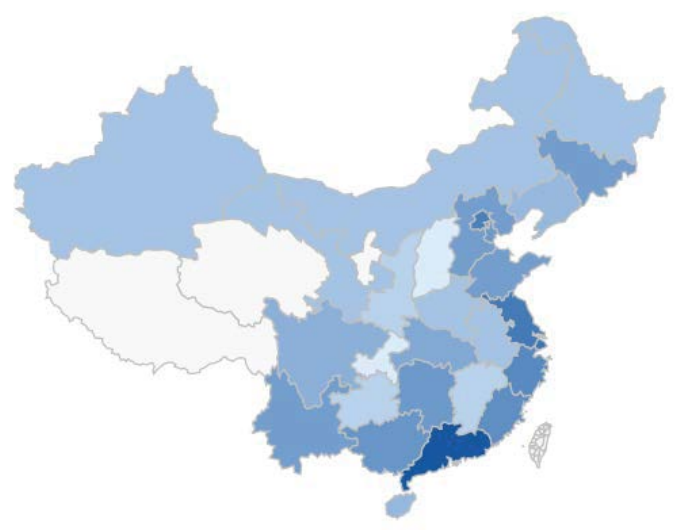

Number of respondents 1

$$
10
$$

Figure 1: Geographic distribution of respondents

\section{Table 1. Summary of Feedback to Questionnaires}

No of Percentage Respondents

Section 1 Characteristics of Surveyed Hospitals

Q2: The type of hospital you are working for

University Hospital 140

Provincial/municipal hospital

Military Hospital $\quad 12 \quad 4.63 \%$

$\begin{array}{lll}\text { Private Hospital } & 4 & 1.54 \%\end{array}$

Q3: The grade of hospital you are working for

\begin{tabular}{|lcc|}
\hline Grade A Class III & 243 & $93.82 \%$ \\
\hline Grade B Class III & 9 & $3.47 \%$ \\
\hline Grade C Class III & 1 & $0.39 \%$ \\
\hline Grade A Class II & 6 & $2.32 \%$ \\
\hline Grade B Class II & 0 & $0.00 \%$ \\
\hline
\end{tabular}

Q4: Is the hospital a general hospital or specialty hospital

\begin{tabular}{|lcc|}
\hline General Hospital & 186 & $71.81 \%$ \\
\hline Specialty Hospital & 72 & $27.80 \%$ \\
\hline Others & 1 & $0.39 \%$ \\
\hline Q5: Bed availability & & \\
\hline$>2000$ Beds & 103 & $39.77 \%$ \\
\hline $1000-2000$ Beds & 111 & $42.86 \%$ \\
\hline $500-1000$ Beds & 29 & $11.20 \%$ \\
\hline$<500$ Beds & 16 & $6.18 \%$ \\
\hline
\end{tabular}

Q6: Is your hospital qualified by CFDA to conduct clinical trial of new drugs?

Yes, Active projects $>100$

49

$18.92 \%$

\begin{tabular}{|c|c|c|}
\hline $\begin{array}{l}\text { Yes, Active projects between } 50 \\
\text { to } 100\end{array}$ & 57 & $22.01 \%$ \\
\hline Yes, Active projects $<50$ & 135 & $52.12 \%$ \\
\hline No CFDA accreditation & 18 & $6.95 \%$ \\
\hline \multicolumn{3}{|c|}{ Section 2: IIT summary and management infrastructure } \\
\hline \multicolumn{3}{|l|}{ Q7: Is your hospital conducting IIT? } \\
\hline Yes, Active projects $>100$ & 31 & $11.97 \%$ \\
\hline $\begin{array}{l}\text { Yes, Active projects between } \\
50-100\end{array}$ & 20 & $7.72 \%$ \\
\hline Yes, Active projects $<50$ & 188 & $72.59 \%$ \\
\hline No IIT project running & 20 & $7.72 \%$ \\
\hline \multicolumn{3}{|c|}{$\begin{array}{l}\text { Q8: Does your hospital establish a dedicated team to manage } \\
\text { or supervise IIT? }\end{array}$} \\
\hline $\begin{array}{l}\text { Yes, managed by an independent } \\
\text { department }\end{array}$ & 14 & $5.41 \%$ \\
\hline $\begin{array}{l}\text { Yes, under the management of } \\
\text { new drug clinical trial office. }\end{array}$ & 114 & $44.02 \%$ \\
\hline $\begin{array}{l}\text { Yes, under the management by } \\
\text { the Scientific Department }\end{array}$ & 89 & $34.36 \%$ \\
\hline $\begin{array}{l}\text { Yes, managed by another } \\
\text { department }\end{array}$ & 8 & $3.09 \%$ \\
\hline No & 34 & $13.13 \%$ \\
\hline \multicolumn{3}{|c|}{$\begin{array}{l}\text { Q9: Is the specific SOP/Guidance established to oversight IIT } \\
\text { in your hospital? }\end{array}$} \\
\hline $\begin{array}{l}\text { Yes, specific SOP/ Guidance set } \\
\text { up }\end{array}$ & 58 & $22.39 \%$ \\
\hline $\begin{array}{l}\text { No, follow the same SOP/ } \\
\text { Guidance with new drug clinical } \\
\text { trial }\end{array}$ & 136 & $52.51 \%$ \\
\hline No & 65 & $25.10 \%$ \\
\hline
\end{tabular}

\section{Section 3: Oversight and Management of IIT}

Q10: Is ITT reviewed prior to conduction in your hospital?

Yes, reviewed by the

management office

107

$41.31 \%$

Yes, research committee

reviews that with the presence

of epidemiologists and / or

37

$14.29 \%$

statisticians in the review process

Yes, research board will review,

research committee reviews

that without the presence

of epidemiologists and / or

statisticians in the review process

Q11: Is ITT approved by ethical committee in your hospital?

Yes, must be approved by EC $\quad 230 \quad 88.80 \%$

$\begin{array}{lll}\text { No, not required } & 2 & 0.77 \%\end{array}$

Depends $27 \quad 10.42 \%$

Q12: Is the review criteria to IIT the same as new drug clinical trial?

\begin{tabular}{|lcc|}
\hline Same & 126 & $48.65 \%$ \\
\hline $\begin{array}{l}\text { Different, stricter to IIT and hard } \\
\text { to approve }\end{array}$ & 20 & $7.72 \%$ \\
\hline $\begin{array}{l}\text { Different, more flexible to IIT and } \\
\text { easy to be approved }\end{array}$ & 113 & $43.63 \%$ \\
\hline \begin{tabular}{l} 
Q13: Is Quality Control conducted in IIT in your hospital \\
\hline Yes, 3-4 times annually
\end{tabular} & 44 & $16.99 \%$ \\
\hline Yes, annual QC & 40 & $15.44 \%$ \\
\hline Yes, QC when study closure & 43 & $16.60 \%$ \\
\hline Randomly checking & 61 & $23.55 \%$ \\
\hline
\end{tabular}




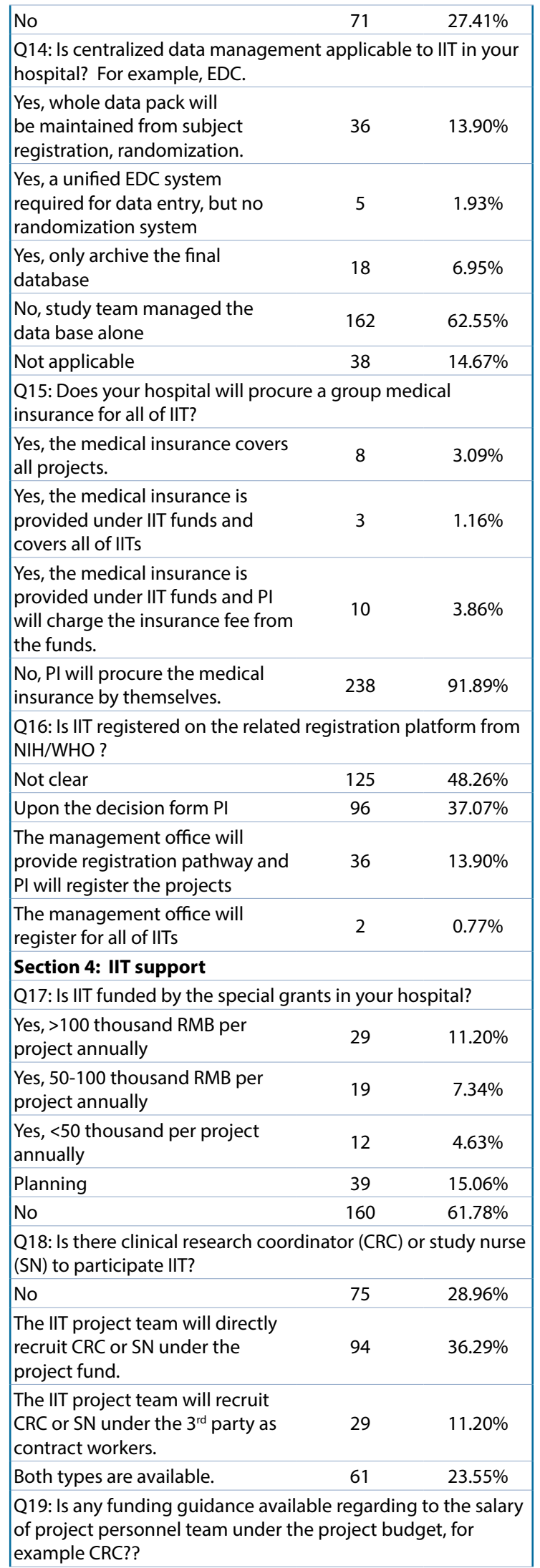

\begin{tabular}{|c|c|c|}
\hline $\begin{array}{l}\text { The salary proportion is no more } \\
\text { than } 20 \% \text { to total budget. }\end{array}$ & 43 & $16.60 \%$ \\
\hline $\begin{array}{l}\text { The salary proportion is no more } \\
\text { than } 30 \% \text { to total budget. }\end{array}$ & 15 & $5.79 \%$ \\
\hline $\begin{array}{l}\text { The salary proportion is no more } \\
\text { than } 50 \% \text { to total budget. }\end{array}$ & 9 & $3.47 \%$ \\
\hline No limitation & 192 & $74.13 \%$ \\
\hline \multicolumn{3}{|c|}{$\begin{array}{l}\text { Q20: Will the principle investigator or staff in IITs be awarded } \\
\text { if their trial result is published on peer review journal or } \\
\text { referenced by treatment guideline? }\end{array}$} \\
\hline $\begin{array}{l}\text { Yes, advantage on promotion and } \\
\text { bonus }\end{array}$ & 53 & $20.46 \%$ \\
\hline Yes, bonus & 79 & $30.50 \%$ \\
\hline Yes, honorary certificates & 0 & $0.00 \%$ \\
\hline Planning & 28 & $10.81 \%$ \\
\hline No & 99 & $38.22 \%$ \\
\hline \multicolumn{3}{|c|}{$\begin{array}{l}\text { Q21: Do you think it makes sense to conduct IITs for the } \\
\text { development in your department? }\end{array}$} \\
\hline Yes, very necessary & 144 & $55.60 \%$ \\
\hline Yes, some degree & 100 & $38.61 \%$ \\
\hline Basically No & 5 & $1.93 \%$ \\
\hline No known & 10 & $3.86 \%$ \\
\hline \multicolumn{3}{|c|}{$\begin{array}{l}\text { Q22: Do you think your colleagues are interested to conduct } \\
\text { IITs in your hospitals? }\end{array}$} \\
\hline Yes, very proactive & 54 & $20.85 \%$ \\
\hline Yes, but lack of capacity & 169 & $65.25 \%$ \\
\hline Not care & 32 & $12.36 \%$ \\
\hline No & 4 & $1.54 \%$ \\
\hline \multicolumn{3}{|l|}{$\begin{array}{l}\text { Q23: What is the limitation do } \\
\text { you think to conduct IITs in China } \\
\text { (multiple choices)? }\end{array}$} \\
\hline Insufficient financial support & 196 & $75.68 \%$ \\
\hline $\begin{array}{l}\text { Lack of scientific knowledge to } \\
\text { design clinical trial }\end{array}$ & 197 & $76.06 \%$ \\
\hline Lack of administrative support & 155 & $59.85 \%$ \\
\hline $\begin{array}{l}\text { Overwhelming project } \\
\text { management issues }\end{array}$ & 176 & $67.95 \%$ \\
\hline $\begin{array}{l}\text { Uncertainty on regulations and } \\
\text { governance }\end{array}$ & 165 & $63.71 \%$ \\
\hline Others: & 11 & $4.25 \%$ \\
\hline
\end{tabular}

Half of respondents were from university hospitals (54.05\%) followed by that from provincial or municipal hospitals (39.77\%). As most university hospitals and provincial hospitals are Grade A Class III hospitals and own over 1000 beds of capacity on average, this in turn reflecting in the following questions, majority of hospitals surveyed are Grade A Class III hospitals (93.82\%) and owns over 1000 beds (82.63\%). Our respondents were invited from the specialty groups with major interest on clinical trials. Nearly all of surveyed hospitals were accredited by CFDA to conduct clinical trials for new drugs (93.05\%).

Most respondents have replied to run IITs as well (Q7, 93.28\%). IITs were mainly supervised by the same 
department to supervise new drug trial (Q8, 44.02\%) or scientific department (34.36\%). Just a smaller amount of hospitals has no administrative governance to IITs at all (13.13\%). In the aspect of SOP system related, a quarter of respondents replied that no SOP or guidance to instruct IIT management at their hospitals (Q9, 25, $10 \%)$. Nevertheless, most hospitals have established a major infrastructure to oversight IITs but still having room to improve.

As summarized at Section 3, prior to initiation, most IITs have been technically reviewed by administrative body or research committee. Independent ethical review was mandatory in majority of hospitals (Q11). Only a small number of ECs will review the project subject to the real case. Most IITs were either reviewed by EC with the same review criteria as new drug trial (Q12 48.65\%) or more flexible criteria (43.64\%). Only $27.41 \%$ of IITs did not receive any QC (Q13). Majority of IITs have QC conducted. It has shown that at current stage, hospitals are raising awareness to improve the quality of IITs. In terms of data management, most investigators have used an independent database to capture the clinical trial data (Q14, 62.55\%); 13.90\% of respondents replied that their hospitals have all IITs under a centralized data management system. Medical insurance coverage is requested by ICH. In this survey, over $90 \%$ of medical insurance in IITs are provided by investigators themselves. The funding source for medical insurance was not disclosed in this survey. A worthy noting issue is that nearly half of IITs have not been registered on the registration platform (Q16, 48.26\%), only a small proportion of respondents confirmed that their administrative office will help them registering the trials (13.90\%).

Our survey also assessed the funding status of IITs in China. Not surprisingly only $23 \%$ of respondents replied that various amount of fund have been provided to run their IIT projects (Q17). Majority of feedback $(61 \%)$ confirmed there is no financial support at all. Nevertheless, CRC or SN is funded in most of IITs (Q18, 71\%). This showed that the investigators in China realized the significant impact of CRC/SN on the study delivery. Respondents acknowledged that IITs will bring them honor upon the trial outcome (Q20, 50.96\%) and IITs can significantly improve the academic performance (Q21, 77\%). However, when considering the interest of their colleagues on IIT conduction, $65 \%$ of respondents complained the lack of capacity constrained their interests on ITT (Q22). At last question Q23, most of respondents shared the same view on the limitations to further develop IIT in China as following: Insufficient financial funding (75.68\%), lack of scientific knowledge (76.06\%), administrative support $(59.85 \%)$, and project management issues $(67.95 \%)$ followed by the uncertainty of regulations and governance (63.71\%).

Based on the survey results, we further evaluated the correlation within each hospital characteristic (Table 2 and Table 3). Most sites have active IITs less than 50 (ranged between 67.4-100\%). Notably, a significant proportion of university hospitals had over 100 active IITs when the survey was undergoing $(18.57 \%, \mathrm{p}<0.05)$. A similar trend has also been seen when analyzing the correlation between hospital size (bed availability) and project numbers (Table 3, $\mathrm{p}<0.05$ ). 62.5-75.86\% of hospitals, regardless the hospital size, have IITs less than 50 . To those hospital sizes over 1000 beds, 12.61 $16.5 \%$ of them had more than 100 active IITs.

The correlation between other 2 important hospital characteristics and investigator interests were also explored separately in Table 4 and Table 5. As shown in Table 4, 26.43\% of university hospital staff

\begin{tabular}{|c|c|c|c|c|c|}
\hline Q7 & $\begin{array}{l}\text { Yes, Active projects } \\
>100\end{array}$ & $\begin{array}{l}\text { Yes, Active projects } \\
\text { between } 50-100\end{array}$ & $\begin{array}{l}\text { Yes, Active projects } \\
<50\end{array}$ & $\begin{array}{c}\text { No CFDA } \\
\text { Accreditation }\end{array}$ & $\begin{array}{l}\text { Number of } \\
\text { respondents }\end{array}$ \\
\hline University Hospital & $\begin{array}{l}18.57 \% \\
(26)\end{array}$ & $\begin{array}{c}10.0 \% \\
(14)\end{array}$ & $\begin{array}{l}67.14 \% \\
(94)\end{array}$ & $\begin{array}{l}4.29 \% \\
(6)\end{array}$ & 140 \\
\hline $\begin{array}{l}\text { Provincial / municipal } \\
\text { hospital }\end{array}$ & $\begin{array}{l}3.88 \% \\
(4)\end{array}$ & $\begin{array}{l}5.83 \% \\
(6)\end{array}$ & $\begin{array}{c}77.67 \% \\
(80)\end{array}$ & $\begin{array}{l}12.62 \% \\
(13)\end{array}$ & 103 \\
\hline Military Hospital & $\begin{array}{l}8.33 \% \\
(1)\end{array}$ & $\begin{array}{l}0.0 \% \\
(0)\end{array}$ & $\begin{array}{c}83.33 \% \\
(10)\end{array}$ & $\begin{array}{l}8.33 \% \\
(1)\end{array}$ & 12 \\
\hline Private Hospital & $\begin{array}{c}0.0 \% \\
(0)\end{array}$ & $\begin{array}{c}0.0 \% \\
(0)\end{array}$ & $\begin{array}{c}100.0 \% \\
\text { (4) }\end{array}$ & $\begin{array}{c}0.0 \% \\
(0)\end{array}$ & 4 \\
\hline $\begin{array}{l}\text { Number of } \\
\text { respondents }\end{array}$ & 31 & 20 & 188 & 20 & 259 \\
\hline
\end{tabular}

Chi-square Test: $p=0.012<0.05$ 


\begin{tabular}{|c|c|c|c|c|c|}
\hline Q5 & $\begin{array}{l}\text { Q7 Yes, Active projects } \\
>100\end{array}$ & $\begin{array}{l}\text { Yes, Active projects } \\
\text { between } 50-100\end{array}$ & $\begin{array}{l}\text { Yes, Active projects } \\
<50\end{array}$ & $\begin{array}{c}\text { No CFDA } \\
\text { Accreditation }\end{array}$ & $\begin{array}{l}\text { Number of } \\
\text { respondents }\end{array}$ \\
\hline$>2000$ & $\begin{array}{c}16.5 \% \\
(17)\end{array}$ & $\begin{array}{c}9.71 \% \\
(10)\end{array}$ & $\begin{array}{c}70.87 \% \\
(73)\end{array}$ & $\begin{array}{l}2.91 \% \\
\text { (3) }\end{array}$ & 103 \\
\hline 2000-1000 & $\begin{array}{c}12.61 \% \\
(14)\end{array}$ & $\begin{array}{c}6.31 \% \\
(7)\end{array}$ & $\begin{array}{c}74.77 \% \\
(83)\end{array}$ & $\begin{array}{c}6.31 \% \\
(7)\end{array}$ & 111 \\
\hline $1000-500$ & $\begin{array}{l}0.0 \% \\
(0)\end{array}$ & $\begin{array}{l}6.9 \% \\
(2)\end{array}$ & $\begin{array}{c}75.86 \% \\
(22)\end{array}$ & $\begin{array}{l}17.24 \% \\
(5)\end{array}$ & 29 \\
\hline$<500$ & $\begin{array}{c}0.0 \% \\
(0)\end{array}$ & $\begin{array}{c}6.25 \% \\
(10)\end{array}$ & $\begin{array}{c}62.5 \% \\
(10)\end{array}$ & $\begin{array}{l}31.25 \% \\
(5)\end{array}$ & 16 \\
\hline $\begin{array}{l}\text { Number of } \\
\text { respondents }\end{array}$ & 31 & 20 & 188 & 20 & 259 \\
\hline
\end{tabular}

Chi-square Test: $p=0.02<0.05$

\begin{tabular}{|c|c|c|c|c|c|}
\hline Q22 & Yes, very proactive & $\begin{array}{l}\text { Yes, but lack of } \\
\text { capacity }\end{array}$ & Not care & No & $\begin{array}{l}\text { Number of } \\
\text { respondents }\end{array}$ \\
\hline \multicolumn{6}{|l|}{ Q2 } \\
\hline University hospital & $\begin{array}{l}26.43 \% \\
(37)\end{array}$ & $\begin{array}{c}60.0 \% \\
(84)\end{array}$ & $\begin{array}{l}12.86 \% \\
(18)\end{array}$ & $\begin{array}{l}0.71 \% \\
(1)\end{array}$ & 140 \\
\hline $\begin{array}{l}\text { Provincial/municipal } \\
\text { public hospital }\end{array}$ & $\begin{array}{l}15.53 \% \\
(16)\end{array}$ & $\begin{array}{c}68.93 \% \\
(71)\end{array}$ & $\begin{array}{c}12.62 \% \\
(13)\end{array}$ & $\begin{array}{l}2.91 \% \\
(3)\end{array}$ & 103 \\
\hline Military hospital & $\begin{array}{l}8.33 \% \\
(1)\end{array}$ & $\begin{array}{c}83.33 \% \\
(10)\end{array}$ & $\begin{array}{l}8.33 \% \\
(1)\end{array}$ & $\begin{array}{c}0.0 \% \\
(0)\end{array}$ & 12 \\
\hline Private hospital & $\begin{array}{l}0.0 \% \\
(0)\end{array}$ & $\begin{array}{c}100.0 \% \\
(4)\end{array}$ & $\begin{array}{l}0.0 \% \\
(0)\end{array}$ & $\begin{array}{c}0.0 \% \\
(0)\end{array}$ & 4 \\
\hline Number of respondents & 54 & 169 & 32 & 4 & 259 \\
\hline
\end{tabular}

Chi-square Test: $p=0.02<0.05$

\begin{tabular}{|c|c|c|c|c|c|c|}
\hline Q4 & Q22 & $\begin{array}{l}\text { Yes, very } \\
\text { proactive }\end{array}$ & $\begin{array}{l}\text { Yes, but lack of } \\
\text { capacity }\end{array}$ & Not care & No & $\begin{array}{l}\text { Number of } \\
\text { respondents }\end{array}$ \\
\hline General Hospital & & $\begin{array}{c}19.35 \% \\
(36)\end{array}$ & $\begin{array}{c}64.52 \% \\
(120)\end{array}$ & $\begin{array}{c}14.52 \% \\
(27)\end{array}$ & $\begin{array}{c}1.61 \% \\
(3)\end{array}$ & 186 \\
\hline Specialist Hospital & & $\begin{array}{c}25.0 \% \\
(18)\end{array}$ & $\begin{array}{c}66.67 \% \\
(48)\end{array}$ & $\begin{array}{l}6.94 \% \\
(5)\end{array}$ & $\begin{array}{c}1.39 \% \\
(1)\end{array}$ & 72 \\
\hline Other & & $\begin{array}{l}0.0 \% \\
(0)\end{array}$ & $\begin{array}{c}100.0 \% \\
(1)\end{array}$ & $\begin{array}{l}0.0 \% \\
(0)\end{array}$ & $\begin{array}{l}0.0 \% \\
(0)\end{array}$ & 1 \\
\hline Number of respondents & & 54 & 169 & 32 & 4 & 259 \\
\hline
\end{tabular}

Chi-square Test: $p=0.02<0.05$

responded in the survey showed very proactive attitude to IITs, significantly higher than those in provincial/ municipal hospitals or military hospitals $(\mathrm{p}<0.05)$. In contrast, majority of staff based in provincial/municipal hospitals and military hospitals felt the lack of capacity constraining their interest $(68.93 \%$ and $83.33 \%$ respectively), as only $60 \%$ in the university hospitals. From another aspect, clinical staff in specialty hospitals expressed relatively higher interest to IITs (25\%, Table 4) than the colleagues in general hospitals (19.35\%). But still most of clinical staff, either in general hospitals or in the specialty hospitals, feels lack of capacity (64.32\% vs. 66.67\% respectively, Table 5).

Funding is critical to a successful delivery of IITs. We evaluated the funding impact on investigator interests, as shown on Table 6. Definitely, the sufficiency of financial funding status affected the willingness of IIT conduction in a great degree. $65.52 \%$ of respondents with funding over 100 thousand RMB are very proactive to conduct IITs. In contrast, $70 \%$ of respondents without IIT funding support are lacked capacity as well as those under planning $69.23 \%$. 


\begin{tabular}{|c|c|c|c|c|c|}
\hline Q22 & Yes, very proactive & $\begin{array}{l}\text { Yes, but lack of } \\
\text { capacity }\end{array}$ & Not care & No & $\begin{array}{l}\text { Number of } \\
\text { respondents }\end{array}$ \\
\hline $\begin{array}{l}\text { Yes, }>100 \text { thousand RMB per } \\
\text { project annually }\end{array}$ & $\begin{array}{l}65.52 \% \\
(19)\end{array}$ & $\begin{array}{l}34.48 \% \\
(10)\end{array}$ & $\begin{array}{l}0.0 \% \\
(0)\end{array}$ & $\begin{array}{l}0.0 \% \\
(0)\end{array}$ & 29 \\
\hline $\begin{array}{l}\text { Yes, } 50-100 \text { thousand RMB } \\
\text { per project annually }\end{array}$ & $\begin{array}{l}31.58 \% \\
(6)\end{array}$ & $\begin{array}{l}57.89 \% \\
(11)\end{array}$ & $\begin{array}{l}10.53 \% \\
(2)\end{array}$ & $\begin{array}{c}0.0 \% \\
(0)\end{array}$ & 19 \\
\hline $\begin{array}{l}\text { Yes, }<50 \text { thousand per } \\
\text { project annually }\end{array}$ & $\begin{array}{l}16.67 \% \\
(2)\end{array}$ & $\begin{array}{l}75.0 \% \\
(9)\end{array}$ & $\begin{array}{l}8.33 \% \\
(1)\end{array}$ & $\begin{array}{l}0.0 \% \\
(0)\end{array}$ & 12 \\
\hline Being planned & $\begin{array}{l}20.51 \% \\
(8)\end{array}$ & $\begin{array}{c}69.23 \% \\
(27)\end{array}$ & $\begin{array}{c}7.69 \% \\
(3)\end{array}$ & $\begin{array}{l}2.56 \% \\
(1)\end{array}$ & 39 \\
\hline No & $\begin{array}{c}11.88 \% \\
(19)\end{array}$ & $\begin{array}{l}70.0 \% \\
(112)\end{array}$ & $\begin{array}{l}16.25 \% \\
(26)\end{array}$ & $\begin{array}{l}1.88 \% \\
(3)\end{array}$ & 160 \\
\hline Number of respondents & 54 & 169 & 32 & 4 & 259 \\
\hline
\end{tabular}

Chi-square Test: $p=0.002<0.05$

\begin{tabular}{|c|c|c|c|c|c|c|}
\hline Q20 & $\begin{array}{l}\text { Yes, advantage } \\
\text { on promotion } \\
\text { and bonus }\end{array}$ & Yes, bonus & $\begin{array}{l}\text { Yes, honorary } \\
\text { certificates }\end{array}$ & Planning & No & $\begin{array}{l}\text { Number of } \\
\text { respondents }\end{array}$ \\
\hline University hospital & $\begin{array}{l}23.57 \% \\
(33)\end{array}$ & $\begin{array}{c}32.86 \% \\
(46)\end{array}$ & $\begin{array}{l}0.0 \% \\
(0)\end{array}$ & $\begin{array}{l}10.71 \% \\
(15)\end{array}$ & $\begin{array}{c}32.86 \% \\
(46)\end{array}$ & 140 \\
\hline $\begin{array}{l}\text { Provincial / municipal } \\
\text { public hospital }\end{array}$ & $\begin{array}{c}16.5 \% \\
(17)\end{array}$ & $\begin{array}{c}31.07 \% \\
(32)\end{array}$ & $\begin{array}{l}0.0 \% \\
(0)\end{array}$ & $\begin{array}{l}9.71 \% \\
(10)\end{array}$ & $\begin{array}{c}42.72 \% \\
(44)\end{array}$ & 103 \\
\hline Military hospital & $\begin{array}{l}16.67 \% \\
(2)\end{array}$ & $\begin{array}{l}0.0 \% \\
(0)\end{array}$ & $\begin{array}{l}0.0 \% \\
(0)\end{array}$ & $\begin{array}{l}25.0 \% \\
(3)\end{array}$ & $\begin{array}{l}58.33 \% \\
(7)\end{array}$ & 12 \\
\hline Private hospital & $\begin{array}{l}25.0 \% \\
(1)\end{array}$ & $\begin{array}{l}25.0 \% \\
(1)\end{array}$ & $\begin{array}{l}0.0 \% \\
(0)\end{array}$ & $\begin{array}{l}0.0 \% \\
(0)\end{array}$ & $\begin{array}{l}50.0 \% \\
(2)\end{array}$ & 4 \\
\hline $\begin{array}{l}\text { Number of } \\
\text { respondents }\end{array}$ & 53 & 79 & 0 & 28 & 99 & 259 \\
\hline
\end{tabular}

Chi-square Test: $p<0.000$

Table 8 Correlation between management infrastructure and IITs QC frequency

\begin{tabular}{|lcccccc|} 
& $\begin{array}{c}\text { Yes. 3-4 } \\
\text { times per } \\
\text { year. }\end{array}$ & $\begin{array}{c}\text { Yes. Once a } \\
\text { year. }\end{array}$ & $\begin{array}{c}\text { Yes. Project } \\
\text { completion } \\
\text { quality check. }\end{array}$ & $\begin{array}{c}\text { Only } \\
\text { random } \\
\text { checks. }\end{array}$ & $\begin{array}{c}\text { No. } \\
\text { Number of } \\
\text { respondents }\end{array}$ \\
\hline $\begin{array}{l}35.71 \% \\
\text { Yes, it is a dedicated management }\end{array}$ & $\begin{array}{c}14.29 \% \\
\text { department }\end{array}$ & $\begin{array}{c}7.14 \% \\
(1)\end{array}$ & $\begin{array}{c}21.43 \% \\
(3)\end{array}$ & $\begin{array}{c}21.43 \% \\
(3)\end{array}$ & 14 \\
\hline Yes, it is managed by a department that & $\begin{array}{c}28.07 \% \\
\text { also manage new drugs clinical trials }\end{array}$ & $\begin{array}{c}17.54 \% \\
(32)\end{array}$ & $\begin{array}{c}22.81 \% \\
(20)\end{array}$ & $\begin{array}{c}21.05 \% \\
(24)\end{array}$ & $\begin{array}{c}10.53 \% \\
(12)\end{array}$ & 114 \\
\hline Yes, it is managed by the Administration & $2.25 \%$ & $13.48 \%$ & $15.73 \%$ & $25.84 \%$ & $42.7 \%$ & 89 \\
of Scientific Research & $(2)$ & $(12)$ & $(14)$ & $(23)$ & $(38)$ & 89 \\
\hline Yes, it is part of other administration & $0.0 \%$ & $37.5 \%$ & $12.5 \%$ & $25.0 \%$ & $25.0 \%$ & 8 \\
department & $(0)$ & $(3)$ & $(1)$ & $(2)$ & $(2)$ & 8 \\
\hline No & $14.71 \%$ & $8.82 \%$ & $2.94 \%$ & $26.47 \%$ & $47.06 \%$ & 34 \\
\hline Number of respondents & $(5)$ & $(3)$ & $(1)$ & $(9)$ & $(16)$ & 34 \\
\hline
\end{tabular}

Chi-square Test: $p<0.000$

On Table 7, the correlation between hospital types and IIT interest motivation was analyzed. As the mainstream of clinical research sectors, $56.43 \%$ of university hospitals have provided either promotion advantage or bonus to attract staff conducting IITs. While provincial/municipal hospitals (47.57\%) and military hospitals $(58.33 \%)$ have no planning to promote IIT activities.

Finally, we revealed the correlation between the management infrastructure and QC performance in Table 8. If IITs are under a dedicated management department, various frequency of QC was conducted. 
$35.71 \%$ of IITs will be monitored by QC activities 3-4 times annually if a dedicated team takes an administrative responsibility. If there is no IITs governance structure in the hospital, $47.6 \%$ of hospitals did not run QC towards IITs.

\section{Discussion}

From 2004 to 2013, number of IIT in clinical oncology area has been increased from 10 in 2004 to nearly 200 in 2013 [4]. The booming of clinical trial in China and local innovative drug pharma has pushed CFDA reformation finally since July 2015. A white-paper like article has been published to illustrate the coming regulation policy reformation route and Oncological IIT development [5]. It is anticipating that in coming decades, more and more IITs will be conducted in China, even when the drug or clinical intervention is not approved yet. In order to provide more supportive solution to facilitate IIT development, it is necessary to understand current status of IIT management and governance infrastructure, from the aspect of hospital administration team.

As far as known, this survey is a first study collecting the management information of IITs in China comprehensively. The data reporting here is representable because the majority of respondents are from the most active academic sectors or public healthy sectors which run clinical trials in China and involved into IITs conduction or oversight. 259 respondents from 231 hospitals provided the first-handed IITs management / government infrastructure at their hospitals and their opinions towards IITs. The reason why data has been analyzed based on the responder rather than hospitals were because some individual opinions should be evaluated and the small number of respondents from same institution won't impact the major outcome.

Overall, the IITs are still conducted by university hospitals in a large proportion as well as more supportive solution have been consolidated in the university hospitals. This is not surprising because university hospitals traditionally take a significant role to conduct clinical trials globally. China is not an exception. The unique phenomenon is that most hospitals are also credited by CFDA to conduct registration trials of new drugs. Most clinicians have accumulated experience during sponsor-initiated trials. This in turn is helpful for them to start up the IITs based on the experience for protocol development, patient informed consent, database management etc.
A well-established management infrastructure will provide more oversight to IIT conduction. In this investigation, $78.38 \%$ of respondents have governance department in the hospital (Q7). SOP and/ or Guidance were established to provide a frame on the IITs conduction as well as reviewed body in most hospitals. These will some degree ensure that IITs are in compliance with ICH. In addition, IIT QC has been conducted more frequently when the hospitals have a dedicated team to oversight their performance and quality (Table 8). This survey demonstrated the effort of Chinese clinical colleagues to ensure IITs in compliance with ICH from the governance level. We used to search PubMed or other academic searching engines and did not find the governance information of IITs overseas. It will be further worthwhile to investigate whether there is the difference on IITs governance between China and other mature societies.

According to the 2016 annual report of DanaFarber Cancer Institute (DFCI) [6] and MD Anderson Cancer Center (MDACC) [7] in United States, DFCI has 354 million US\$ fund on clinical research and this number is 780.5 million US\$ in MDACC. Only 5.6 million US\$ was reported by Sun Yat-Sen University Cancer Center to support clinical research. A huge gap on funding between academic centers from 2 countries is also epitome of clinical trial funding status of 2 countries. In China, IIT conduction is lacked off sufficient financial support but it is crucial to study activities. The funding incapacity has significant constrained the willingness to IITs, as reported in this survey. It is not realistic to fully rely on the government funding which is very competitive and the public grant is limited on clinical research. The professional bodies can establish the collaborative mechanism with pharma industry and social funds to support local IITs. In China, CTONG (Chinese Thoracic Oncology Group) has been published the primary outcome of 2 Phase III trials: OPTIMAL [8] and INFORM [9] on Lancet Oncology, which were supported by pharmaceutical companies and government funds. CTONG is a good case for academia to have collaborative trials conducted to answer the clinical dilemmas or the benefits/risks assessment of spontaneous drug use in an unapproved indication, which are not driven by pharmaceutical companies in most circumstances.

Our finding suggested that investigators should be encouraged to complete the clinical research training to improve their capability to design protocols and excursion capability even though they have chances to participate in the trials initiated by sponsors. Indeed, 
this sort of training can be also provided by online platform, which will be more cost saving and efficient solution to balance their heavy workload and training needs.

Limitation of this survey is that we cannot have a balanced distribution of responders across different types of clinical institutions, especially private hospitals, which will increase their presence in coming decade. Nevertheless, the imbalanced distribution of clinical trial activities is presented in the real world and hard to avoid. The other issue is that in the questionnaire, we did not collect information furthermore to check what kind of system to manage clinical trial metrics or trial document, as well as the type of clinical trial data capture system (paper, spreadsheet or commercial EDC) and statistical analysis plan endorsement, which are critical to management. It is hoping to address these questions in coming surveys.

\section{Conclusion}

This survey firstly revealed the real status of IITs in China crossing different types of hospitals and addressed the supportive directions to IIT development in China.

\section{Executive summary}

Objective: With the rapid increasing clinical trials in China in recent years, there has been rising concern on the management of investigator initiated trials. Compared with the trials sponsored by pharmaceutical companies, IIT is facing practical challenges in China due to the lack of experience by investigator and immature regulatory circumstances. We conducted an internet-based survey to understand the overall picture of IITs management in China.

Methods: An internet-based questionnaire was developed and the staff of clinical trial offices from different types of hospitals was invited to provide response via mobile based App or online website in 2 weeks. We have collected the responses from the following aspects: administrative and governance infrastructure, ethical review, project management, funding resources and research staff management.

Results: From December 8 to 20, 2016, a total of 259 responses were collected from the staffs that are mainly responsible for the clinical trial management and scientific research based in the different clinical facilities.

Conclusion: In China, three key factors are important to improve the management on IITs: funding support, staffing resourcing and regulatory guidance.

\section{References}

1. Yang, Minzhi. Understanding and thoughts about investigatorinitiated clinical trials. Chinese J New Drugs 23: 387 (2014).

2. NHFPC. Guidance for the administration of clinical research projects by medical and health institutions. 10 16, 2014.

3. National Health and Family Planning Commission of People's republic of China. Biomedical ethical review approach involving human beings. [Online] 10 12, 2016.

4. Wu YL, Zhang H, Yang Y. Cancer drug development in China: recent advances and future challenges. Drug Discovery Today 20: 766 (2015).

5. Zhou Q, Chen XY, Yang ZM, Wu YL. The changing landscape of clinical trial and approval processes in China. Nature Reviews Clin Oncol 14: 579 (2017).
6. Dana-Farber Cancer Institute 2016 Fact Book.

7. MD Anderson Cancer Center Quick Fact 2016.

8. Zhou C, Wu YL, Chen G, Feng J, Liu XQ, Wang C, et al. Erlotinib versus chemotherapy as first-line treatment for patients with advanced EGFR mutation-positive non-smallcell lung cancer (OPTIMAL, CTONG-0802): a multicentre, open-label, randomised, phase 3 study. Lancet Oncology 12: 735 (2011).

9. Zhang L, Ma S, Song X, Han B, Cheng Y, Huang C, et al. Gefitinib versus placebo as maintenance therapy in patients with locally advanced or metastatic non-small-cell lung cancer (INFORM; C-TONG 0804): a multicentre, doubleblind randomised phase 3 trial. Lancet Oncology 13: 466 (2012). 